\title{
Online education, social media and other topics
}

\author{
EAIT editorial 17-4
}

\author{
Arthur Tatnall
}

Published online: 27 March 2012

(C) Springer Science+Business Media, LLC 2012

Several of the articles in this issue are concerned with online education and social media, but one deals with ICT literacy in Nigerian universities and another with ICT and the teaching of Islamic studies in the UK, again demonstrating the breadth of this field. In 2013 we will have two special issues presenting the best papers from two academic conferences. We are open also to other special issues (probably from 2014) on other relevant topics. If you have any ideas on this, please contact me (Arthur.Tatnall@vu.edu.au).

In this last issue for 2012 the first article is by Jared Keengwe and David Georgina on: 'The digital course training workshop for online learning and teaching'. The authors point out that a primary concern with Information Technology training has been that such training focuses on the technical aspects of learning management system (LMS) platforms and pedagogy-enhancing software without any concern for the content of the courses. The Digital Course Training Workshop (DCTW) approach examined in this article addresses this concern by supporting a content-first approach. The article aims to stimulate reflections on the need for systematic faculty professional development programs and activities to help higher education faculty in the transition process from traditional to online courses.

The second article: 'ICT literacy among undergraduates in Nigerian universities' is by AirenEdaleAdetimirin. The article relates a study to investigate the availability, use of Information and Communication Technology and the ICT literacy skills of undergraduates in seven Nigerian universities. The study found that computers, telephone and the Internet were the three technologies mostly used by the undergraduates, although more on an occasional basis. The three major factors affecting the ICT literacy of the undergraduates were identified as irregular power supply, inadequate ICT and limited duration of the use of the ICT. The author advocates that for increased ICT literacy among undergraduates, university administrators need to

\footnotetext{
A. Tatnall $(\bowtie)$

Victoria University, Melbourne, Australia

e-mail: Arthur.Tatnall@vu.edu.au
} 
introduce courses on ICT competency to all students, especially first year students, and to encourage all lecturers to use ICT for teaching and learning.

The next article, by AylaGöl is titled: 'Constructing knowledge: An effective use of educational technology for teaching Islamic studies in the UK' and aims to show how educational technology can be used effectively to help students construct knowledge when teaching Islamic studies in the UK. The first part of this paper summarizes the differences between information sharing and knowledge construction with reference to the essence of knowledge as Aristotelian 'episteme' (theoretical knowledge) and technê (practical knowledge: know-how); and the extent which the former process is created by the use of Information Technology (IT) while the latter is enhanced by Educational Technology (ET), and the second explores how ET can be used effectively to 'provide training in critical and creative thinking skills of students' as an integral part of producing useful tools and generating practical benefit during their learning process. Finally the article explains why a student centred and researchbased teaching is preferred to traditional research-led method in order to support the construction of knowledge.

Next, Haya El-Ghalayini and Nuha El-Khalili write about: 'An approach to designing and evaluating blended courses'. They begin by noting that despite the increased interest in electronic courses, the literature shows that adopting e-learning does not guarantee improved learning as mixing technology and content does not necessarily yield effective learning. The article proposes a systematic design process for developing blended courses for undergraduate higher education in which the design process is based on instructional design theories and utilized taxonomies of Bloom, Redeker and Guerra. A case study is presented to demonstrate this design approach on a System Analysis and Design blended course that is under development.

'Towards an understanding of the learning processes that occur in synchronous online seminars for the professional development of experienced educators' was written by Kathy Seddon, Keith Postlethwaite, Matthew James and Kevin Mulryne. The authors point out that Web conferencing tools offer a range of modes of interaction including audio, chat, text, desktop sharing, presentations and video conferencing and so have potential for multi-process learning. The research reported in this article investigated the ways in which multi-process learning using these tools can be understood. It asked 'What insights can be gained into the learning processes occurring in synchronous online seminars involving experienced educators?

The final article looks at: 'How are campus students using social media to support their studies? An explorative interview study'. It was contributed by Stefan Hrastinski and Naghmeh M. Aghaee. The article suggests that social media hype has created a lot of speculation among educators on how these media can be used to support learning. The reported explorative interview study explores how campus students perceive using social media to support their studies and the perceived benefits and limitations compared with other means. Although the vast majority of the respondents use social media frequently, a "digital dissonance" can be noted, because few of them feel that they use such media to support their studies. The authors argue that teaching strategy plays a key role in supporting students in moving from using social media to support coordination and information retrieval to also using such media for collaborative learning, when appropriate. 


\section{Appreciation of reviewers}

This last issue of the year also contains a list of the reviewers who completed reviews in 2010-2011. For all their hard work and for helping to deliver timely decisions to authors, the publisher and I thank the following individuals who contributed reviews in the period January 2010-December 2011. We applaud your efforts and your dedication to the community.

Buket Akkoyunlu

Pavlo Antonenko

Zoran Čekerevac

Aasim Azooz

Konstantinos Baltzis

Moshe Barak

Georges-Louis Baron

David Benzie

M. N. Bessagnet

Mithun Bhaskar

Ben Blake

Torsten Brinda

Cathy Burnett

Rodwell Chitiyo

Ana Paula Couceiro Figueira

Eva Dakich

Bill Davey

Lin Deng

Helen Drenoyianni

Thomas Fischer

Andrew Fluck

Sebastien George

Philippa Gerbic

Suki Goodman

Monique Grandbastien

Mark Hellen

Jeanne Ho

Alan Hogarth

Ling $\mathrm{Hu}$

Jimmy Jaldemark

Hao Jiang

Anthony Jones

Mike Joy

Michail Kalogiannakis

D. Kanellopoulos

Y. Karagiorgi

Yaacov Katz

Mike Kendall

Steve Kennewell
John Kirkman

A. Kirkwood

Maria Kordaki

Rune Krumsvik

H. C. Lam

Wilfred Lau

Siong Hoe Lau

Cathy Lewin

Sandy C. Li

Maria Limniou

Ju Long

Avril Loveless

A. Macris

Francisco Madera

J. Magenheim

Elham Majd

E. I. Malama

Gail Marshall

Dragana Martinovic

Harvey Mellar

Tassos Mikropoulos

D. Mioduser

Punya Mishra

I. Molnar

Jari Multisilta

Uma Natarajan

Len Newton

Maggie Niess

Christopher O'Mahony

R. Or-Bach

N. Papadopoulos

Marina Papastergiou

Kevin Parker

Don Passey

David Passig

Shivaji Patil

Tjeerd Plomp

Edson Riccio

Ian Selwood 
Manjit Sidhu

Rafet Sipal

A. Solomonidou

Anna Spyrtou

Arthur Tatnall

Scott Turner

Arthur Tatnall

Editor-in-Chief, EAIT
Joke Voogt

Peter Waker

Tsung Juang Wang

Mary Webb

Ros Yahaya

Allan Yuen 